\title{
A review of the Santiago Purple Heron Ardea purpurea bournei, with a report of a new colony
}

\author{
C. J. HAZEVOET
}

\section{Summary}

The Santiago Purple Heron Ardea (purpurea) bournei is endemic to the island of Santiago, Cape Verde Islands. In contrast to nominate purpurea, it nests high in the crowns of large trees. During the 1950 and 1960 , the total population was probably $c .75$ pairs, mainly at the now defunct heronry at São Domingos. After the disappearance of that colony during the early 1970s, the only known nesting site was at Boa Entrada, Santa Catarina region, comprising less than 10 pairs. In January 1991, a new colony was discovered at Banana, Ribeira Montanha, with $c$. 20 recently used nests of which $2-3$ had large young in January-February. The current population is thought not to exceed c. 20 pairs. Breeding occurs from late August to March. Apart from two old records in April, there are no records from the non-breeding season. Probably the birds disperse into the mountainous interior of the island after breeding and feed on the dry hillsides. The causes of the decline are unclear, but scarcity of suitable nest-sites and deteriorating climatic conditions may be significant. Because of the extremely small population, the birds and their nesting sites must be protected by law and the local people informed about the birds and their need for protection; educational materials are being developed.

A Garça-vermelha de Santiago Ardea (purpurea) bournei é endêmica à Ilha de Santiago nas Ilhas de Cabo Verde. Em contraste com a A. purpurea continental, nidifica no alto das grandes árvores. Durante os anos de 1950 e 1960, a população total era provavelmente cerca de 75 casais, principalmente na colônia em São Domingos, agora defunta. Depois do desaparecimento da colônia durante os anos de 1970, o único sítio de reprodução era em Boa Entrada na região de Santa Catarina, constituíndo menos de 10 pares. Em janeiro de 1991 uma nova colônia foi descoberta em Banana, Ribeira Montanha, com cerca de 20 ninhos recentemente ocupados, dos quais $2-3$ tinham grandes jovens em janeirofevereiro. Pensa-se que a população atual não excede cerca de 20 pares. Reprodução ocorre em fins de agosto até março. A parte de dois velhos registros em abril, não existem registros do período não-reprodutivo. Provavelmente as aves se dispersam no interior montanhoso da ilha, depois de reproduzir, e alimentam-se nas colinas secas. As causas do declínio não são bem percebidas, mas a escassez de sítios de nidificação e a deterioração de condições climáticas podem ser significantes. Devido à população minúscula, as aves e seus sítios de nidificação devem ser protegidos por lei, e o povo local deve ser informado sobre as aves e a necessidade de protege-las. Materiais educativos estão sendo desenvolvidos.

The Santiago Purple Heron Ardea purpurea bournei is confined to the island of Santiago in the Cape Verde Islands (Figure 1). Although discovered breeding, and collected in 1951 (Bourne 1955), it was not described as a new subspecies until 15 years later (de Naurois 1966). Recently, de Naurois (1988) has suggested 


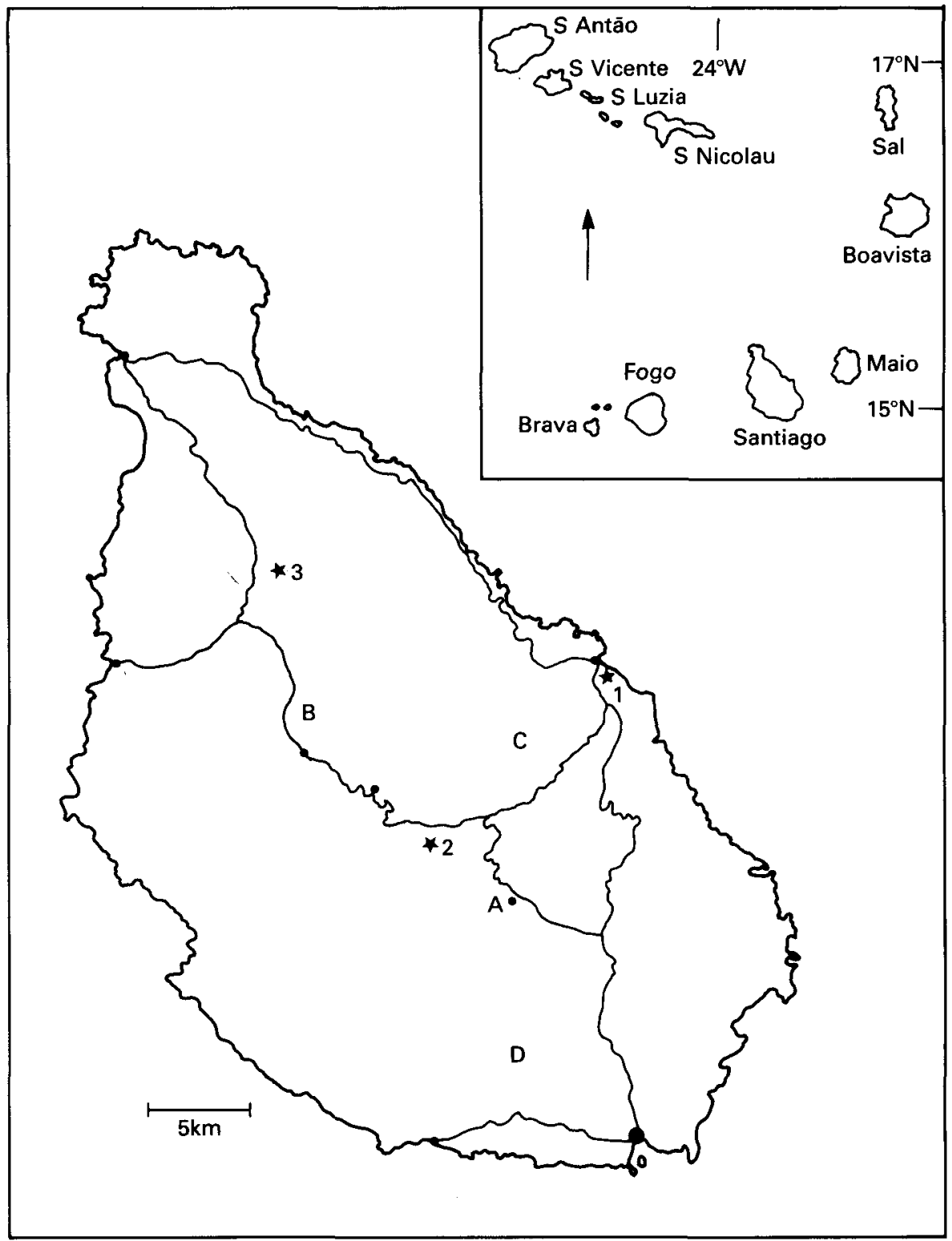

Figure 1. The island of Santiago, Cape Verde Islands, showing (former) breeding sites of the Santiago Purple Heron (A, São Domingos; B, Boa Entrada; C, Banana; D, Trindade) and locations of observations away from the colonies (1, Pedra Badejo lagoon; 2, São Jorge dos Órgãos; 3, Serra da Malagueta). Solid lines = main roads; dots = main towns and villages. Inset: the Cape Verde Islands.

that $A . p$. bournei should perhaps be considered a separate species, analogous to the Grey Heron A. cinerea monicae of Mauritania, first described as a distinct subspecies (Jouanin and Roux 1963) and now also regarded as meriting specific rank (Erard et al. 1986). A. c. monicae only breeds on two or three islets in the 
Banc d'Arguin, Mauritania (von Westernhagen 1970, Campredon 1987). Both forms represent island populations on the edge of the nominate race's distribution. They are primarily distinguished by their very pale plumage, presumably an adaptation to hot and arid habitats, but there are no biometrical differences with the nominate races (Erard et al. 1986, de Naurois 1988). In both, a reversal in breeding habits has taken place. While $A$. cinerea is generally a tree-nesting species, $A$. c. monicae is a ground-breeder, and while $A$. purpurea usually breeds low in bushes and reedbeds, $A$. $p$. bournei has taken to the crowns of large trees. Remarkably, the Purple Herons that breed in the Senegal delta, opposite the Cape Verde Islands, and elsewhere in the Afrotropics, are indistinguishable from the nominate race (Hancock and Elliott 1978, de Naurois 1988), and the same applies for the Grey Herons that were recently found breeding in the Saloum delta, Senegal, where A. c. monicae is a regular visitor (Baillon 1989). This indicates that both bournei and monicae have been derived from considerably older stock, whilst the Afrotropical breeding populations of nominate purpurea and cinerea represent comparatively recent arrivals. Nominate purpurea is a rare straggler (only four records) to the Cape Verde Islands (Hazevoet in prep.), while nominate cinerea is a common winter visitor to the Banc d'Arguin (Lamarche 1988). In neither case does there appear to be any interbreeding between the local and visiting populations. Whether such isolated island populations should be considered full species or not remains a matter of opinion and approach. However, this does not change the fact that these are reproductively isolated and distinct forms of considerable evolutionary interest. If alloted specific rank, $A$. bournei would require inclusion in the list of single-island endemics compiled by Johnson and Stattersfield (1990), and would, of course, be eligible for treatment as a threatened species.

\section{Distribution and breeding}

On its discovery in 1951, there was a thriving colony of the then unnamed subspecies at São Domingos (Bourne 1955), which was still in a flourishing state during the 1960s (de Naurois 1966, Bannerman and Bannerman 1968). Although the colony was said to be strictly protected by the landowner (de Naurois 1966), this did not prevent the nesting trees being felled, and the birds disappeared from São Domingos about 20 years ago, as I was informed by local inhabitants. In March 1963, another colony was discovered at Boa Entrada, Santa Catarina region, which held two or three pairs at that time, and during the same year there may have been a breeding attempt at Trindade (de Naurois 1966). In September 1969, seven specimens were collected by J. V. dos Santos (Frade 1976), presumably at São Domingos.

Nothing was heard about the birds thereafter until March 1985, when one was observed in a tree near São Jorge dos Orgãos by a group of British naturalists (J. Hall and P. Hall in litt. 1990). In October 1988, I started to make observations at the Boa Entrada colony, then the only known breeding site. Here, nests had been found by de Naurois (1966) in a mango tree Mangifera indica and in a huge $20 \mathrm{~m}$ kapok Ceiba pentandra (Figure 2). I only observed the birds in the latter, although mango trees are still plentiful in the area. The colony was visited seven times (October-November and February-May) during the years 1988-1991. Data 


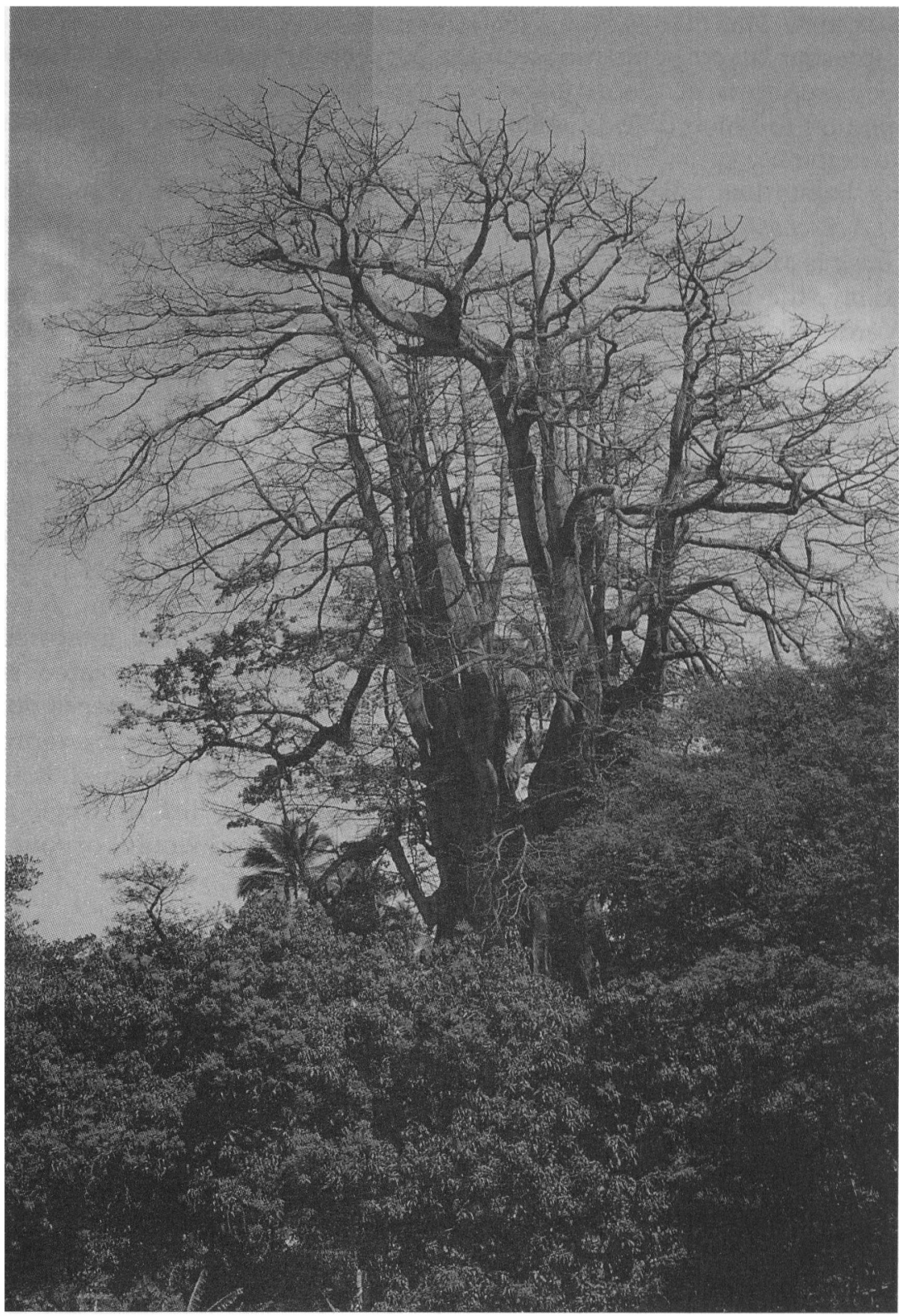

Figure 2. Breeding site of the Santiago Purple Heron in kapok Ceiba pentandra, Boa Entrada, Santa Catarina region, March 1990. (Photo: C. J. Hazevoet)

from single visits in September 1988 and October 1989 were received from J. P. Ledant (in litt. 1988) and R. L. Miller (in litt. 1989) respectively. The highest number of adults present was five on 6 November 1988 and again five on 2 February 1991. There were six occupied nests in September-November 1988 and four in October 1989. On 23 October 1988, six young were observed in the nesting tree, one of which was $2-3$ weeks old while the others were 5-6 weeks. 


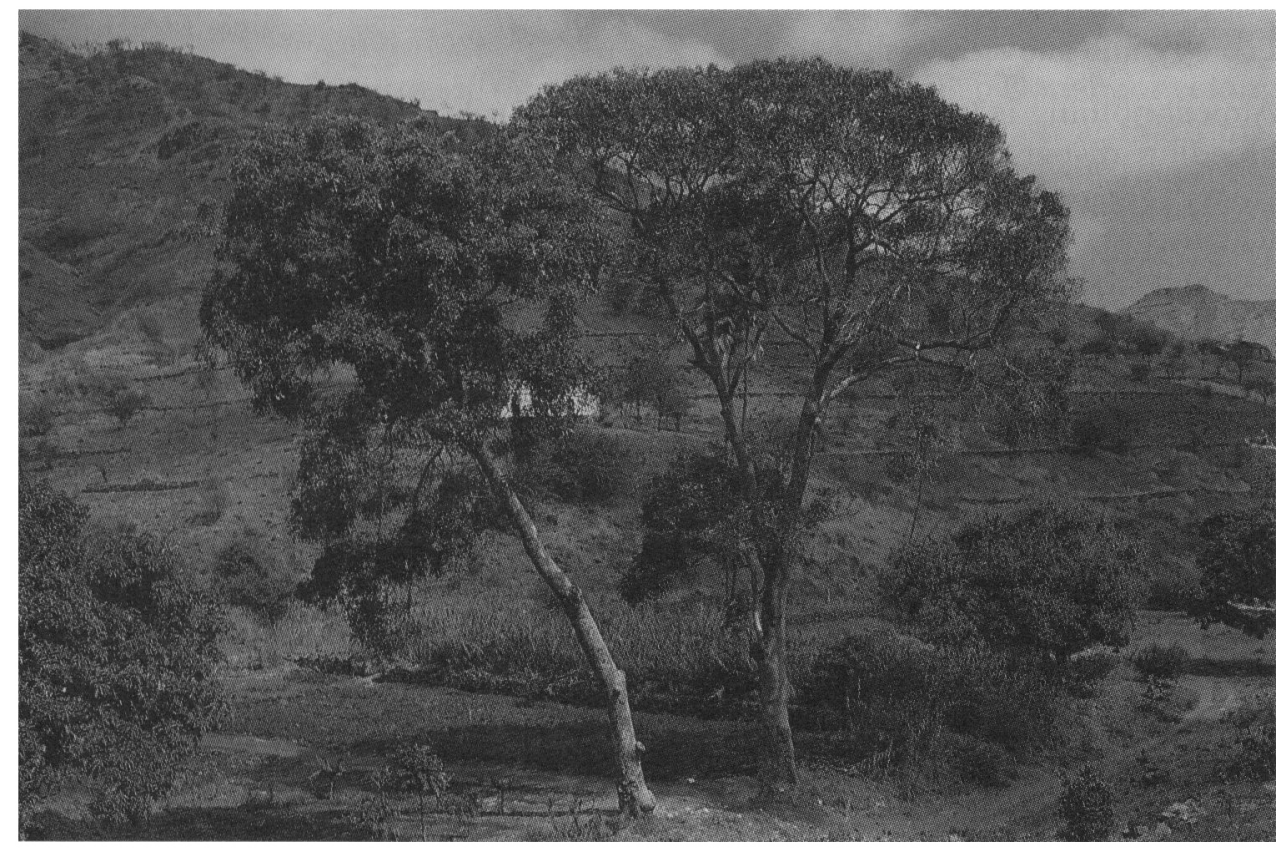

Figure 3. Breeding site of the Santiago Purple Heron in mahogany Khaya senegalensis, Banana, Ribeira Montanha, January 1991. (Photo: C. J. Hazevoet)

During visits in May 1989 and April 1990, no herons were present. The latest spring dates are of one adult on 3 March 1990 and one full-grown young on 21 March 1991. The population at Boa Entrada was thought to be less than 10 pairs.

In November 1990, Purple Herons were seen in the Montanha region (A. Jansen in litt. 1990). On 31 January 1991, I found a colony, until then unknown, at Banana in the Ribeira Montanha. The colony was situated in a medium-sized mahogany Khaya senegalensis (Figure 3). At least 20 nests could be detected in the canopy of the tree but only two or three of them appeared to be occupied. Three full-grown young were wandering through the crown of the tree; they were fed from time to time by adults arriving from and flying off in various directions. In total, four adults were observed. One week later, the juveniles were still present but by 21 March all birds had left the colony. Because the observations were made late in the breeding season, it is not yet certain how large this colony is. In view of the number of nests present, it may well be that the known population of the Santiago Purple Heron has been doubled by its discovery. It seems reasonable to assume that the Banana colony was formed by birds from the abandoned São Domingos colony (c. $7.5 \mathrm{~km}$ to the south), as older inhabitants told me that the herons had not been there "very long".

The breeding season appears to last from late August to March, starting after the rains when food is abundant. Birds were seen in flight near the São Domingos colony on 3 August, while on 21 September they were beginning to sit (Bourne 1955). Occasionally there may be a second brood in spring as de Naurois (1966) found eggs in March and Bannerman and Bannerman (1968) reported very young birds in early February. 


\section{Ecology and movements}

Almost nothing is known about the Santiago Purple Heron's ecology and postbreeding dispersion. Observations away from the colonies are rare. Bourne (1955) saw it several times (August-September) in irrigated areas, but the birds usually fed on dry ground around cultivated areas. Bannerman and Bannerman (1968) reported seeing it stalking its prey on stony hillsides in February. In 1969 (no month given), de Naurois (1988) saw a few birds on the northern slopes of the Serra de Malagueta, also a dry environment. During the years 1988-1991, I only once saw a bird (in flight) away from the colonies, at São Jorge dos Orgãos, 23 September 1988, the same location where the species was seen in March 1985, as mentioned above. As I regularly stayed at São Jorge dos Orgãos during these years and know the area well, these two observations appear to have been coincidental. There is certainly no colony there.

On 8 and 14 April 1924, the Blossom South Atlantic Expedition took three specimens (which remained undescribed) at "Lagoa", presumably (one of) the lagoons south of Pedra Badejo (skins in the American Museum of Natural History, New York, and Peabody Museum of Natural History, New Haven), and one was seen there on 6 August 1951 (Bourne 1955, W. R. P. Bourne in litt. 1990). During regular visits to this site during the years 1986-1991, covering all months except July and August, I never saw it there. These lagoons are frequented by good numbers of waders (Hazevoet 1992b), while resident Little Egret Egretta garzetta and migrant $A$. cinerea are regular visitors. Moreover, Intermediate Egret E. intermedia (twice), Squacco Heron Ardeola ralloides (once), and Spoonbill Platalea leucorodia (probably an annual visitor), have been observed here (de Naurois 1965, Hazevoet 1990, 1992a). So the lagoons seem to suit waders and herons of various species as well as Spoonbills, but they apparently do not attract the Santiago Purple Heron (although it has occurred there in the past). This may be due to its preference for feeding on the dry hill-slopes, but its rarity may also play a role, offering only the slight chance of encountering it. Moreover, Bannerman and Bannerman (1968) reported considerable reedbeds along the lagoons in February 1966; these have now vanished and the edges of the lagoons barely have any vegetation at all. It seems possible that the herons visited the Pedra Badejo lagoons more often in the past when there was still some "marshland habitat" present there.

The few observations away from the breeding sites suggest that the birds feed mainly on the dry hill-slopes in the interior of the island. Stomach contents given by Bourne (1955) and de Naurois (1966) included lizards, rats, mice and various insects. All known records of the Santiago Purple Heron are from August to March, i.e. the breeding season, except those in April 1924. There are no records from late April to July, and it is unknown where the birds remain during the non-breeding season. Probably they disperse into the interior of the island and, because of their very small numbers, are difficult to encounter in the very mountainous country. 


\section{Population size}

Bourne (1955) did not provide total numbers of pairs at the São Domingos colony in 1951. However, it appears to have been in a good condition at that time. Information from the 1960 s is somewhat confused. De Naurois (1966) reported 30 pairs at São Domingos and 2-3 pairs at Boa Entrada. His estimate of 100-200 pairs at that time must have been due to an error (R. de Naurois in litt. 1991). Later, the same author stated that there was one principal colony (presumably the one at São Domingos), one less important colony, and two sites with 2-3 pairs, but he did not detail the locations (de Naurois 1969). In still another publication, de Naurois (1984) said that during the 1960 s there were three or four colonies with a total of some tens of birds. In the account of their visit to the São Domingo site in February 1966, Bannerman and Bannerman (1968) wrote that "the Purple Heron is evidently in a flourishing position", and estimated the number of occupied nests at 50-60 in the main part of the colony with more nests elsewhere in the valley. If it is assumed that there were some 75 pairs during the mid-1960s, then the current population of c. 20 pairs indicates a dramatic decline.

\section{Causes of decline}

We can only speculate about why the Santiago Purple Heron has declined so strongly. No direct persecution appears to take place. During the years 19881991, inhabitants at both Boa Entrada and Banana seemed to be aware that the heron's feeding habits are beneficial to agriculture, and at least left the birds alone. The São Domingos colony received (temporarily) protection from the landowner and it is not clear why the nesting-trees were eventually cut down. Possibly the herons have suffered from the droughts that persisted in the islands from the late 1960s until the early 1980s, although they must have survived other such droughts in the past. Another limiting factor may be the lack of suitable nesting sites. Santiago is the most densely populated island in the archipelago, it is intensively cultivated, and large trees are rare. So the São Domingos birds found few opportunities for new settlements when their nesting-trees were destroyed, although there are still several large trees in the immediate surroundings that offer seemingly suitable nesting sites. Moreover, the collection of about a dozen specimens at São Domingos during the 1960s (see de Naurois 1966, 1988, Frade 1976), could not have added to the welfare of the herons and may even have induced them to leave the spot. On the other hand, the introduction of mice and rats by man has provided an additional and considerable foodsource. The African Toad Bufo regularis has also been introduced and is now locally abundant.

Apparently the birds are rather tolerant of human presence, as all colonies are or were situated near villages. It may well be, however, that breeding in the crowns of trees itself evolved in reaction to the presence of men. Breeding low in bushes seems out of the question nowadays in view of the high rate of disturbance at such sites. Contrary to popular belief, the Cape Verde Islands were never wooded, except perhaps in the higher regions. The original vegetation before the arrival of man, during the fifteenth century, seems to have been 
mainly of a shrub-like type covering the mountain slopes with open savanna on the plains (Lobin and Ohm 1987). The better-watered valleys, which are now the ones most intensively cultivated, probably had a more luxurious growth of bushes and reeds. The herons probably bred in the moister ribeiras in the same way as their congeners still do elsewhere. Whether the Santiago Purple Heron ever had a wider distribution in the Cape Verde Islands remains a matter of speculation, although it seems possible that this was the case during periods when the climate was moister and more temperate. Subfossil remains of reedbeds have been found on Sal (Chevalier et al. 1935), and it seems likely that the present lagoons on the islands of Boavista and Maio (which are both very dry today), were larger and had a swampy habitat during the climatic optimum between 12,000 and 4,000 years ago (see Moreau 1963). When the climate began to deteriorate and became drier, the Purple Herons may have found their last resort in the relatively lush valleys of Santiago. However, the population perhaps never counted more than a couple of hundred pairs, even at times when it perhaps had a wider distribution in the islands.

\section{Conservation}

In view of the extremely small population, protective measures are urgently needed. These should include both the birds and their breeding sites. This was advocated more than 25 years ago by de Naurois (1964), apparently without much effect. However, with the growing interest in nature conservation in the Cape Verde Islands, stimulated by the National Parks and Protected Areas Programme of the National Agricultural Research Institute (INIA), in cooperation with ICBP (Netherlands Section), there may at last be a chance to preserve this interesting taxon, with its intriguing adaptation to a hot and arid climate. Recently, an information leaflet has been produced for distribution among the local population at the breeding sites, and the preparation of material about the herons for use in the local schools is planned for the near future.

\section{Acknowledgements}

I am grateful to Bill Bourne, Pam and John Hall, Anna Jansen, Jean-Paul Ledant, Lynn Miller and René de Naurois for providing me with unpublished information on the Santiago Purple Heron. During the years 1988-1991, my work in the Cape Verde Islands was supported by the International Council for Bird Preservation (Netherlands Section), the Netherlands Foundation for International Nature Protection (van Tienhoven Stichting), the J. C. van der Hucht Fonds, the Martina de Beukelaar Stichting, the Netherlands Society for the Protection of Birds (Vogelbescherming Internationale Projecten), the Dierenrampenfonds, and the Netherlands Ministry of Agriculture, Nature Management and Fisheries (Directie Natuur-, Milieu- en Faunabeheer). In the Cape Verde Islands, working facilities were provided by the Instituto Nacional de Investigação Agrária and the Ministry of Rural Development and Fisheries (MDRP). I want to thank Tom van der Have, René de Naurois, Kees Roselaar and Jan Wattel for their comments on a draft of this paper. 


\section{References}

Baillon, F. (1989) Découverte d'une colonie nicheuse de Héron cendré (Ardea cinerea L.) au Sénégal. Alauda 57: 233.

Bannerman, D. A. and Bannerman, W. M. (1968) History of the birds of the Cape Verde Islands. Birds of the Atlantic Islands, 4. Edinburgh: Oliver and Boyd.

Bourne, W. R. P. (1955) The birds of the Cape Verde Islands. Ibis 97: 508-556.

Campredon, P. (1987) La reproduction des oiseaux d'eau sur le Parc National du Banc d'Arguin (Mauritanie) en 1984-1985. Alauda 55: 187-210.

Chevalier, A., Joleaud, L. and Petit, G. (1935) Les dépôts quaternaires de l'ancien cratère de Pedra de Lume (île de Sal, archipel du Cap-Vert). C. R. Acad. Sci. Paris 200: 1334-1335.

Erard, C., Guillou, J. J. and Mayaud, N. (1986) Le Héron blanc du Banc d'Arguin Ardea monicae. Ses affinités morphologiques. Son histoire. Alauda 54: 161-169.

Frade, F. (1976) Aves do arquipélago de Cabo Verde (Colecção do Centro de Zoologia da J.I.C.U.). Garcia de Orta, Sér. Zool. 5: 47-58.

Hancock, J. and Elliott, H. (1978) The herons of the world. London: London Editions.

Hazevoet, C. J. (1990) Notes on new and rare migrants in the Cape Verde Islands. Bull. Brit. Orn. Club 110: 207-212.

Hazevoet, C. J. (1992a) Further notes on migrants in the Cape Verde Islands. Bull. Brit. Orn. Club 112: 61-64.

Hazevoet, C. J. (1992b) Migrant and resident waders in the Cape Verde Islands. Wader Study Group Bull. 64: 46-5o.

Johnson, T. H. and Stattersfield, A. J. (1990) A global review of island endemic birds. Ibis 132: $167-180$.

Jouanin, C. and Roux, F. (1963) Une race nouvelle de Héron cendré Ardea cinerea monicae. Oiseau et R.F.O. 33: 103-106.

Lamarche, B. (1988) Liste commentée des oiseaux de Mauritanie. Etud. Sahar. Ouest-Afr. 1(4): $1-164$.

Lobin, W. and Ohm, P. (1987) Forschungsreisen in ein Entwicklungsland. Biologen arbeiten auf den Kapverdischen Inseln. Natur und Mus. 117: 301-333.

Moreau, R. E. (1963) Vicissitudes of the African biomes in the late Pleistocene. Proc. Zool. Soc. London 141: 395-421.

de Naurois, R. (1964) Les oiseaux des Iles du Cap Vert. Suggestions en vue de leur sauvegarde. Garcia de Orta 12: 609-619.

de Naurois, R. (1965) Faits nouveaux concernant le peuplement avien de l'Archipel du Cap-Vert. C. R. Acad. Sci. Paris 260: 5911-5914.

de Naurois, R. (1966) Le Héron pourpré de l'Archipel du Cap Vert Ardea purpurea bournei ssp. nov. Oiseau et R.F.O. 36: 89-94.

de Naurois, R. (1969) Notes brèves sur l'avifaune de l'archipel du Cap Vert. Faunistique, endémisme, écologie. Bull. Inst. Fond. Afr. Noire Sér. A, 31: 143-218.

de Naurois, R. (1984) Contribution à l'ornithologie de l'Archipel du Cap Vert: reproducteurs menacés d'extinction, nicheurs occasionnels, oiseaux mentionnés par erreur. Bol. Mus. Mun. Funchal 36: 38-50.

de Naurois, R. (1988) Ardea (purpurea) bournei endémique de l'lle de Santiago (Archipel du Cap Vert). Alauda 56: 261-268.

von Westernhagen, W. (1970) Über die Brutvögel der Banc d'Arguin (Mauretanien). J. Orn. 111: 206-226.

\section{J. HAZEVOET}

Institute of Taxonomic Zoology, University of Amsterdam, P.O. Box 4766, 1009 AT Amsterdam, The Netherlands. 